\title{
High-spin iron(II) complexes with mono-phosphorylated 2,6-diaminopyridine ligands
}

\author{
Christan Schröder-Holzhacker ${ }^{1} \cdot$ Berthold Stöger $^{2} \cdot$ Ernst Pittenauer $^{2}$ • \\ Günther Allmaier $^{2} \cdot$ Luis F. Veiros ${ }^{3} \cdot$ Karl Kirchner ${ }^{1}$
}

Received: 25 January 2016/Accepted: 7 March 2016/Published online: 30 March 2016

(c) The Author(s) 2016. This article is published with open access at Springerlink.com

\begin{abstract}
Several new monophosphorylated 2,6-diaminopyridine ligands bearing $\mathrm{PiPr}_{2}$ and $\mathrm{P}_{\mathrm{Bu}} \mathrm{Bu}_{2}$ units $\left(\mathrm{PN}^{\mathrm{NH} 2}{ }_{-i \mathrm{Pr}} \mathrm{PN}^{\mathrm{NH} 2}{ }_{-}-\mathrm{Bu}, \mathrm{PN}^{\mathrm{NHMe}}{ }_{-i \mathrm{Pr}}\right.$, and $\left.\mathrm{PN}^{\mathrm{NHEt}}{ }_{-i \mathrm{Pr}}\right)$ are prepared by treatment of the respective 2,6-diaminopyridines with the chlorophosphines $\mathrm{P}_{\mathrm{Pr}} \mathrm{Cl}$ and $\mathrm{P} t \mathrm{Bu}_{2} \mathrm{Cl}$ in the presence of a base. Treatment of anhydrous $\mathrm{FeCl}_{2}$ with 1 equiv of these afforded the tetracoordinated coordinatively unsaturated $14 \mathrm{e}^{-}$complexes $\left[\mathrm{Fe}\left(\kappa^{2} P, N-\mathrm{PN}^{\mathrm{NH} 2}-\right.\right.$ $\left.i \mathrm{Pr}) \mathrm{Cl}_{2}\right]$ and $\left[\mathrm{Fe}\left(\kappa^{2} P, N-\mathrm{PN}^{\mathrm{NH} 2}-t \mathrm{Bu}\right) \mathrm{Cl}_{2}\right]$, while with $\mathrm{PN}^{\mathrm{NHMe}}{ }_{-} i \mathrm{Pr}$ and $\mathrm{PN}^{\mathrm{NHEt}}{ }_{-} i \mathrm{Pr}$ a phosphine transfer reaction of a second PN ligand took place to yield the known PNP pincer complexes $\left[\mathrm{Fe}\left(\kappa^{3} P, N, P-\mathrm{PNP}^{\mathrm{Me}}-i \mathrm{Pr}\right) \mathrm{Cl}_{2}\right]$ and $\left[\mathrm{Fe}\left(\kappa^{3} P, N, P-\mathrm{PNP}^{\mathrm{Et}}-i \mathrm{Pr}\right) \mathrm{Cl}_{2}\right]$. The four-coordinate complexes $\left[\mathrm{Fe}\left(\kappa^{2} P, N-\mathrm{PN}^{\mathrm{NH} 2}-i \mathrm{Pr}\right) \mathrm{Cl}_{2}\right]$ and $\left[\mathrm{Fe}\left(\kappa^{2} P, N-\mathrm{PN}^{\mathrm{NH} 2}{ }_{-}\right.\right.$ $t \mathrm{Bu}) \mathrm{Cl}_{2}$ ] did not react with $\mathrm{CO}$ and the formation of iron PNC pincer complexes was not observed. The reason for the reluctance to add CO was investigated in detail by DFT calculations.
\end{abstract}

Karl Kirchner

kkirch@mail.tuwien.ac.at

1 Institute of Applied Synthetic Chemistry, Vienna University of Technology, Getreidemarkt 9/163-OC, 1060 Vienna, Austria

2 Institute of Chemical Technologies and Analytics, Vienna University of Technology, Getreidemarkt 9, 1060 Vienna, Austria

3 Centro de Química Estrutural, Instituto Superior Técnico, Universidade de Lisboa, Av. Rovisco Pais No. 1, 1049-001 Lisbon, Portugal

\section{Graphical abstract}

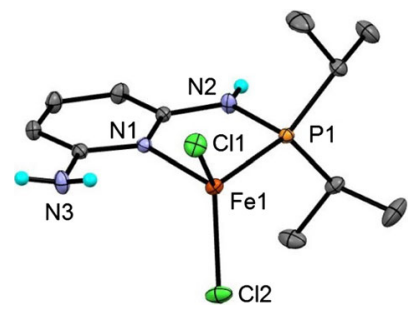

Keywords Iron - Aminophosphine ligands . DFT calculations - Carbon monoxide

\section{Introduction}

Among the many ligand systems that can be found in the chemical literature, pincer ligands play an important role and their complexes have attracted tremendous interest due to their high stability, activity, and variability [1-5]. Pincer ligands are often planar scaffolds consisting of an anionic or neutral central aromatic backbone tethered to two, mostly bulky, two-electron donor groups by different spacers where steric, electronic, and stereochemical parameters can be manipulated by modifications of the substituents at the donor sites and/or the spacers. Phosphine-based PCP and PNP type ligands having central C and $\mathrm{N}$ donors have received the most attention.

In the present contribution we aimed at an in situ synthesis of iron complexes with a new type of pincer ligand, namely a PNC pincer ligand, where the pyridine backbone is connected to an aminophosphine and a carbamoyl moiety (Scheme 1). Obviously, the prerequisite for these reactions is strong coordination of $\mathrm{CO}$ to the metal center 
Scheme 1

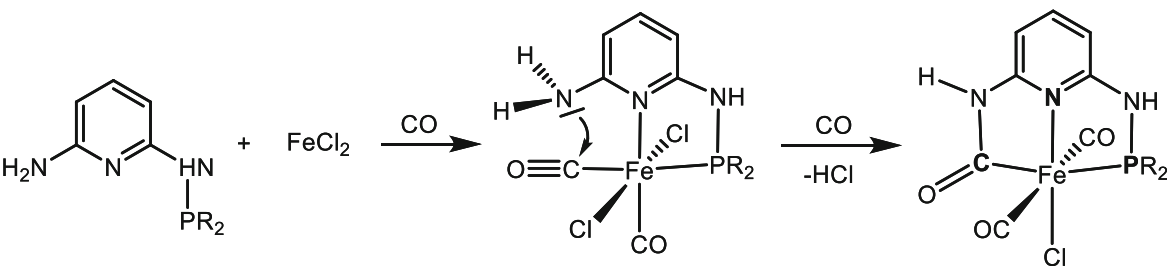

[6]. The carbamoyl moieties may be formed via an intramolecular attack of the free amine substituent at an electrophilic coordinated $\mathrm{CO}$. It has to be noted that the formation of carbamoyl ligands was already reported by the reaction of rhenium and ruthenium carbonyl complexes with amine-substituted nitrogen-containing heterocycles [7-10]. Moreover, this approach was also adapted to synthesize ferracyclic carbamoyl structures [11, 12].

We describe here reactions of mono-phosphorylated 2,6diaminopyridine ligands with $\mathrm{FeCl}_{2}$ in the presence of $\mathrm{CO}$ as well reactions with $\mathrm{Fe}(\mathrm{CO})_{4} \mathrm{Br}_{2}$. In the latter, $\mathrm{CO}$ is already coordinated to the metal center. Mechanistic studies, based on DFT calculations, dealing with the coordination of $\mathrm{CO}$ are also presented.

\section{Results and discussion}

The new PN ligands $\mathrm{PN}^{\mathrm{NH} 2}-i \mathrm{Pr}(\mathbf{1 a}), \mathrm{PN}^{\mathrm{NH} 2}-t \mathrm{Bu}(\mathbf{1 b})$, $\mathrm{PN}^{\mathrm{NHMe}}-i \mathrm{Pr}(\mathbf{1 c})$, and $\mathrm{PN}^{\mathrm{NHEt}}-i \operatorname{Pr}(\mathbf{1 d})$ are prepared conveniently in 45-99\% yield by treatment of the respective 2,6-diaminopyridines with 1 equiv of the chlorophosphines $\mathrm{PiPr}_{2} \mathrm{Cl}$ and $\mathrm{P} t \mathrm{Bu}_{2} \mathrm{Cl}$ in the presence of a base $\left(\mathrm{NEt}_{3}\right.$ or $n$ BuLi) (Scheme 2). The crude product had to be purified by flash chromatography to remove unreacted starting material and the doubly phosphorylated by-product PNP-iPr and $\mathrm{PNP}-t \mathrm{Bu}$ [13]. All reactions were carried out in toluene or toluene/THF at temperatures between 25 and $90{ }^{\circ} \mathrm{C}$ for $15 \mathrm{~h}$. The ligands were isolated as air stable solids or oils and were characterized by elemental analysis, ${ }^{1} \mathrm{H},{ }^{13} \mathrm{C}\left\{{ }^{1} \mathrm{H}\right\}$,

\section{Scheme 2}

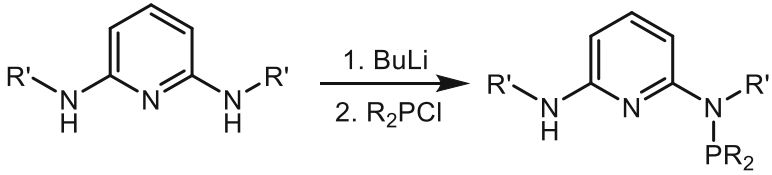

1a $\mathrm{R}=i \mathrm{Pr}, \mathrm{R}^{\prime}=\mathrm{H}$ 1b $R=t B u, R^{\prime}=H$ 1c $\mathrm{R}=i \mathrm{Pr}, \mathrm{R}^{\prime}=\mathrm{Me}$ 1d $R=i \operatorname{Pr}, R^{\prime}=E t$ and ${ }^{31} \mathrm{P}\left\{{ }^{1} \mathrm{H}\right\}$ NMR spectroscopy. Most diagnostic is the ${ }^{31} \mathrm{P}\left\{{ }^{1} \mathrm{H}\right\}$ NMR spectrum exhibiting a singlet at 47.4, 58.2, 70.0, and $78.8 \mathrm{ppm}$ for $\mathbf{1 a - 1 d}$, respectively. In the ${ }^{1} \mathrm{H}$ NMR spectrum the $\mathrm{NH}_{2}$ and $\mathrm{NH}$ protons give rise to a slightly broadened singlet in the range of 3.02-4.19 ppm, while the $\mathrm{NH} i \operatorname{Pr}_{2} \mathrm{NH} t \mathrm{Bu}_{2}$ protons in $\mathbf{1 a}$ and $\mathbf{1 b}$ exhibit doublets at 4.40 and $4.67 \mathrm{ppm}$, with $J_{H P}$ coupling constants of 10.7 and $11.0 \mathrm{~Hz}$, respectively. All other resonances are unremarkable and are not discussed here.

Treatment of anhydrous $\mathrm{FeCl}_{2}$ with 1 equiv of the $\mathrm{PN}$ ligands $\mathrm{PN}-i \mathrm{Pr}(\mathbf{1 a})$ and $\mathrm{PN}-t \mathrm{Bu}(\mathbf{1 b})$ in $\mathrm{THF}$ at room temperature afforded the tetracoordinated coordinatively unsaturated $14 \mathrm{e}^{-}$complexes $\left[\mathrm{Fe}\left(\kappa^{2} P, N-\mathrm{PN}^{\mathrm{NH} 2}-i \mathrm{Pr}\right) \mathrm{Cl}_{2}\right]$ (2a) and $\left[\mathrm{Fe}\left(\kappa^{2} P, N-\mathrm{PN}^{\mathrm{NH} 2}-t \mathrm{Bu}\right) \mathrm{Cl}_{2}\right](\mathbf{2 b})$ in 79 and $81 \%$ isolated yields (Scheme 3 ). These complexes are air sensitive both in the solid state and in solution and are poorly soluble in most common solvents. They display large paramagnetic shifted ${ }^{1} \mathrm{H}$ NMR spectra. At room temperature the line widths are relatively narrow and in the case of 2a the proton resonances could be readily assigned on the basis of integration. The isopropyl methyl hydrogen atoms appear at $16.2(6 \mathrm{H})$ and $-3.4 \mathrm{ppm}(6 \mathrm{H})$, the $\mathrm{CH}$ protons give rise to a signal at $150.7 \mathrm{ppm}(2 \mathrm{H})$, whereas the pyridine hydrogen atoms are centered at $54.4(1 \mathrm{H}), 45.7(1 \mathrm{H})$, and $-19.7 \mathrm{ppm}(1 \mathrm{H})$. The $\mathrm{NH}$ and $\mathrm{NH}_{2}$ protons could not be detected (Scheme 3).

Since ESI-MS enables not only the detection and the study of reaction substrates and products but also shortlived reaction intermediates and decomposition products as they are present in solution, complex $\mathbf{2 a}$ was investigated by means of this technique. A methanolic solution of $\mathbf{2 a}$ was subjected to ESI-MS analysis in the positive ion mode.

Under the so-called "soft ionization" conditions in the electrospray source, the ESI mass spectrum of $\left[\mathrm{Fe}\left(\kappa^{2} P, N\right.\right.$ $\left.\mathrm{PN}^{\mathrm{NH} 2}-i \mathrm{Pr}\right) \mathrm{Cl}_{2}$ ] (2a) shows prominent peaks at $\mathrm{m} /$ $z=541.2$ and 226.1 assignable to the mononuclear species $\left[\mathrm{Fe}\left(\kappa^{2} P, N-\mathrm{PN}{ }^{\mathrm{NH} 2}-i \mathrm{Pr}\right)_{2} \mathrm{Cl}\right]^{+}\left([\mathrm{M}+\mathrm{PN}-\mathrm{Cl}]^{+}\right)$together with the protonated $\mathrm{PN}^{\mathrm{NH} 2}-i \mathrm{Pr}$ ligand (1a), respectively. The formation of $\left[\mathrm{Fe}\left(\kappa^{2} \mathrm{P}, N-\mathrm{PN} \mathrm{NH}^{\mathrm{N}}-i \mathrm{Pr}\right)_{2} \mathrm{Cl}\right]^{+}$is unexpected as this compound contains two $\mathrm{PN}^{\mathrm{NH} 2}-i \mathrm{Pr}$ ligands. The fragmentation of the selected $\left[\mathrm{Fe}\left(\mathrm{PN}^{\mathrm{NH} 2}-i \mathrm{Pr}\right)_{2} \mathrm{Cl}\right]^{+}$ion with $\mathrm{m} /$ $z=541.2$ by low energy collision-induced dissociation 
Scheme 3<smiles>[R20]Nc1cccc(N)n1</smiles>

(CID) in an ion trap analyzer resulted in the formation of an ion with $m / z=316.0$ due to the loss of a $\mathrm{PN}^{\mathrm{NH} 2}-i \mathrm{Pr}$ ligand (Fig. 2). Cationic pentacoordinate $\left[\mathrm{Fe}\left(\kappa^{2} P, N-\mathrm{PN}^{\mathrm{R}}-i \mathrm{Pr}\right)_{2-}\right.$ $\mathrm{Cl}]^{+}$complexes bearing two $\mathrm{PN}$ ligands could not be prepared, despite the fact that these species were the most prominent fragment in the ESI MS spectrum.

In addition, the structure of complex $\mathbf{2 a}$ was determined by X-ray crystallography. The molecular structure of $\mathbf{2 a}$ is depicted in Fig. 1 with selected bond distances and angles given in the caption. The structure of the four-coordinate complexes $\left[\mathrm{Fe}\left(\kappa^{2} P, N-\mathrm{PN}^{\mathrm{NH} 2}-i \mathrm{Pr}\right) \mathrm{Cl}_{2}\right]$ (2a) shows a distorted tetrahedral coordination environment around the iron center. All bond lengths are consistent with a high-spin electron configuration of $\mathrm{Fe}^{2+}$ and in reasonable accord with other crystallographically characterized four-coordinate $\mathrm{Fe}$ (II) dihalide complexes featuring aminophosphine co-ligands [13-16] (Fig. 2).

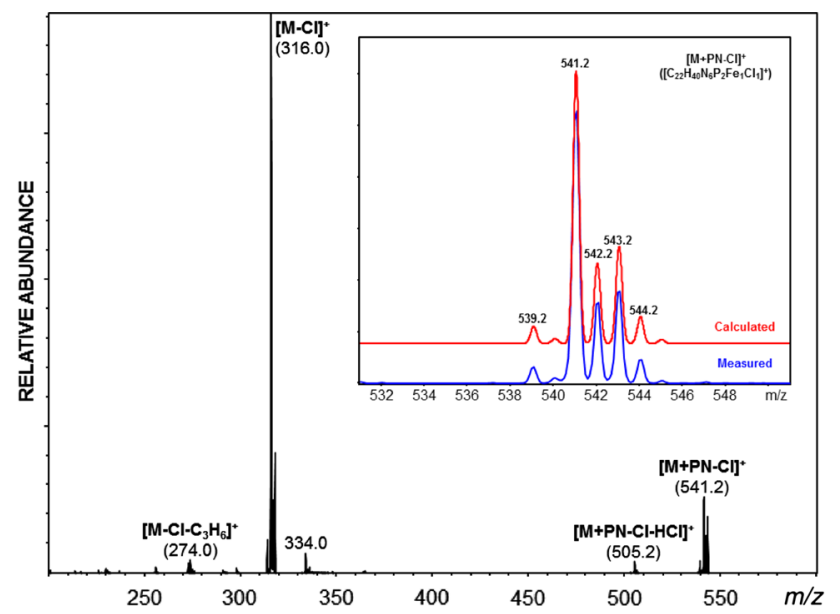

Fig. 1 MS/MS (low energy CID)-spectrum of in-source-generated $\left[\mathrm{Fe}\left(\kappa^{2} P, N-\mathrm{PN}^{\mathrm{NH} 2}-i \mathrm{Pr}\right)_{2} \mathrm{Cl}\right]^{+}\left([\mathrm{M}+\mathrm{PN}-\mathrm{Cl}]^{+}\right)(\mathrm{m} / \mathrm{z}=541.2)$ precursor ions in $\mathrm{CH}_{3} \mathrm{OH}$. Inset shows the calculated and measured isotopic pattern of the cation $\left[\mathrm{Fe}\left(\kappa^{2} P, N-\mathrm{PN}^{\mathrm{NH} 2}-i \mathrm{Pr}\right)_{2} \mathrm{Cl}\right]^{+}$ $\left([\mathrm{M}+\mathrm{PN}-\mathrm{Cl}]^{+}\right)$. All mass calculations and mass assignments are based on the most abundant iron isotope ${ }^{56} \mathrm{Fe}$ and the $\mathrm{Cl}$ isotope of lowest mass $\left({ }^{35} \mathrm{Cl}\right)$

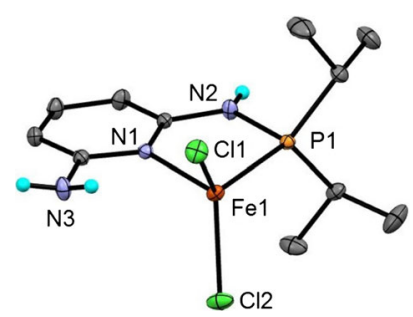

Fig. 2 Structural view of $\left[\mathrm{Fe}\left(\kappa^{2} P, N-\mathrm{PN}^{\mathrm{NH} 2}-i \mathrm{Pr}\right) \mathrm{Cl}_{2}\right]$ (2a) showing $50 \%$ thermal ellipsoids (most $\mathrm{H}$ atoms omitted for clarity). Only one of the two crystallographically independent complexes is shown. Selected bond lengths $(\AA)$ and bond angles $\left({ }^{\circ}\right)$ : Fe1-Cl1 2.2740(4), $\mathrm{Fe} 1-\mathrm{Cl} 2$ 2.2369(4), Fe1-P1 2.4038(5), Fe1-N1 2.106(1), P1-N2 1.690(1), Cl1-Fe1-Cl2 118.81(2), Cl1-Fe1-P1 112.18(2), Cl1-Fe1N1 111.19(3), Cl2-Fe1-P1 119.91, Cl2-Fe1-N1 106.74, Cl1-Fe1P1-N2 104.95(5), Cl2-Fe1-P1

On the other hand, complexation was unsuccessful with the ligand $\mathrm{PN}^{\mathrm{NHMe}}{ }_{-} i \mathrm{Pr}(\mathbf{1 c})$ and $\mathrm{PN}^{\mathrm{NHE}}{ }_{-}-\mathrm{Bu}(\mathbf{1 d})$. Instead, the reaction of $\mathrm{FeCl}_{2}$ with $\mathbf{1 c}$ and $\mathbf{1 d}$ was accompanied by a phosphine transfer step by a second PN ligand to yield the known complexes $\left[\mathrm{Fe}\left(\kappa^{3} P, N, P-\mathrm{PNP}^{\mathrm{Me}}-i \mathrm{Pr}\right) \mathrm{Cl}_{2}\right]$ (3a) and $\left[\mathrm{Fe}\left(\kappa^{3} P, N, P-\mathrm{PNP}^{\mathrm{Et}}{ }_{-i \mathrm{Pr}}\right) \mathrm{Cl}_{2}\right](3 \mathbf{b})[16]$ together with the 2,6-diaminopyridines $\mathbf{4 a}$ and $\mathbf{4 b}$ as well as intractable iron compounds (Scheme 4). Accordingly, the yields of $\mathbf{3 a}$ and 3b are less than $50 \%$ being 46 and $48 \%$, respectively. The products were identified by ${ }^{1} \mathrm{H}$ NMR spectroscopy, after the insoluble inorganic residue was removed by filtration and comparison with the spectra of authentic samples prepared independently [16].

The coordinatively unsaturated complexes $\left[\mathrm{Fe}\left(\kappa^{2} P, N\right.\right.$ $\left.\left.\mathrm{PN}^{\mathrm{NH} 2}-i \mathrm{Pr}\right) \mathrm{Cl}_{2}\right](\mathbf{2 a})$ and $\left[\mathrm{Fe}\left(\kappa^{2} P, N-\mathrm{PN}^{\mathrm{NH} 2}-t \mathrm{Bu} \mathrm{Cl}_{2}\right]\right.$ (2b) where treated with $\mathrm{CO}$ but failed to react (Scheme 3). With $\mathrm{Fe}(\mathrm{CO})_{4} \mathrm{Br}_{2}$ no clean reaction took place and several intractable materials were formed. To rationalize why these complexes do not reacted with $\mathrm{CO}$, the addition of $\mathrm{CO}$ to 2a (denoted as ${ }^{\mathbf{5}} \mathbf{A}$ in Fig. 3) was investigated by means of DFT calculations. While ${ }^{\mathbf{5}} \mathbf{A}$ has a spin-quintet $(S=2)$ ground state, the mono carbonyl complex $\left[\mathrm{Fe}\left(\kappa^{2} P, N-\right.\right.$ $\left.\left.\mathrm{PN}^{\mathrm{NH} 2}-i \mathrm{Pr}\right)(\mathrm{CO}) \mathrm{Cl}_{2}\right](\mathbf{B})$ may exist either as spin-quintet or a spin-singlet $(S=0)$. The energy profile associated with 


\section{Scheme 4}
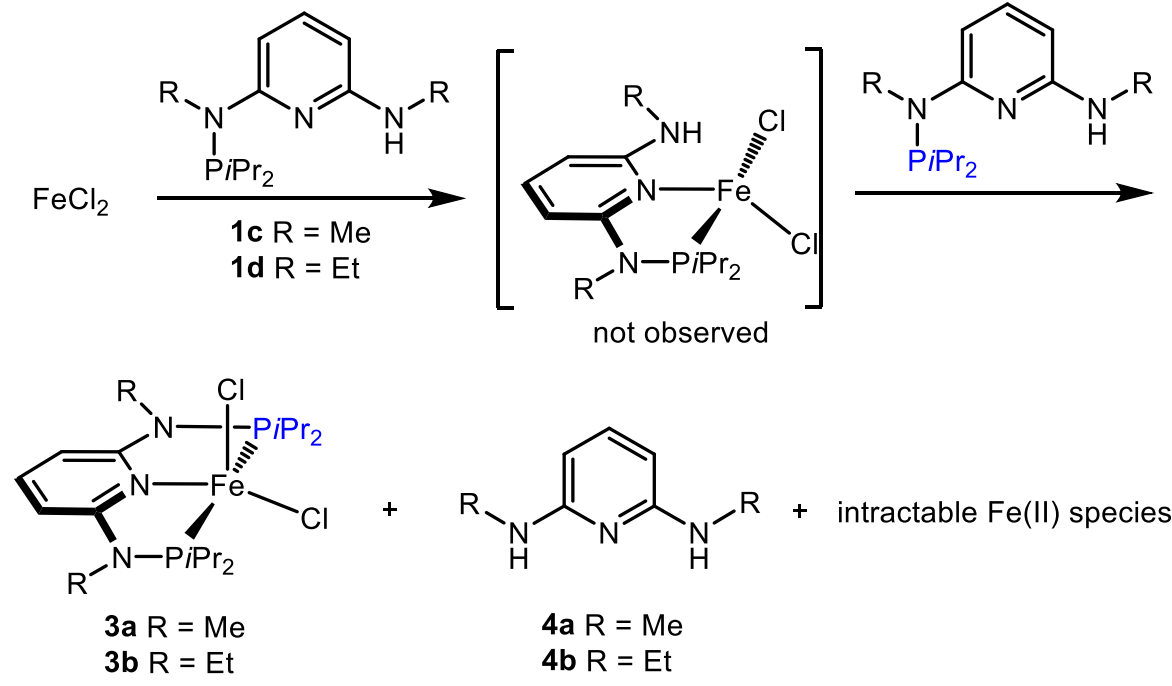

Fig. 3 Energy profile (OPBE) for the addition of $\mathrm{CO}$ to $\left[\mathrm{Fe}\left(\kappa^{2} P, N\right.\right.$-PNP- $\left.\left.i \mathrm{Pr}\right) \mathrm{Cl}_{2}\right]$ (2a) yielding the illusive complex $\left[\mathrm{Fe}\left(\kappa^{2} P, N\right.\right.$-PNP- $\left.\left.i \mathrm{Pr}\right)(\mathrm{CO}) \mathrm{Cl}_{2}\right]$ (B). The energy values $(\mathrm{kJ} / \mathrm{mol})$ are relative to the separated reagents, and the values in italic represent the free energies. The plain curve corresponds to the spin-quintuplet PES $(S=2)$, and the dashed curve to the spin-singlet PES $(S=0)$. The $\mathrm{Fe}-\mathrm{C}(\mathrm{CO})$ distance $(\AA)$ along the reaction coordinate is indicated

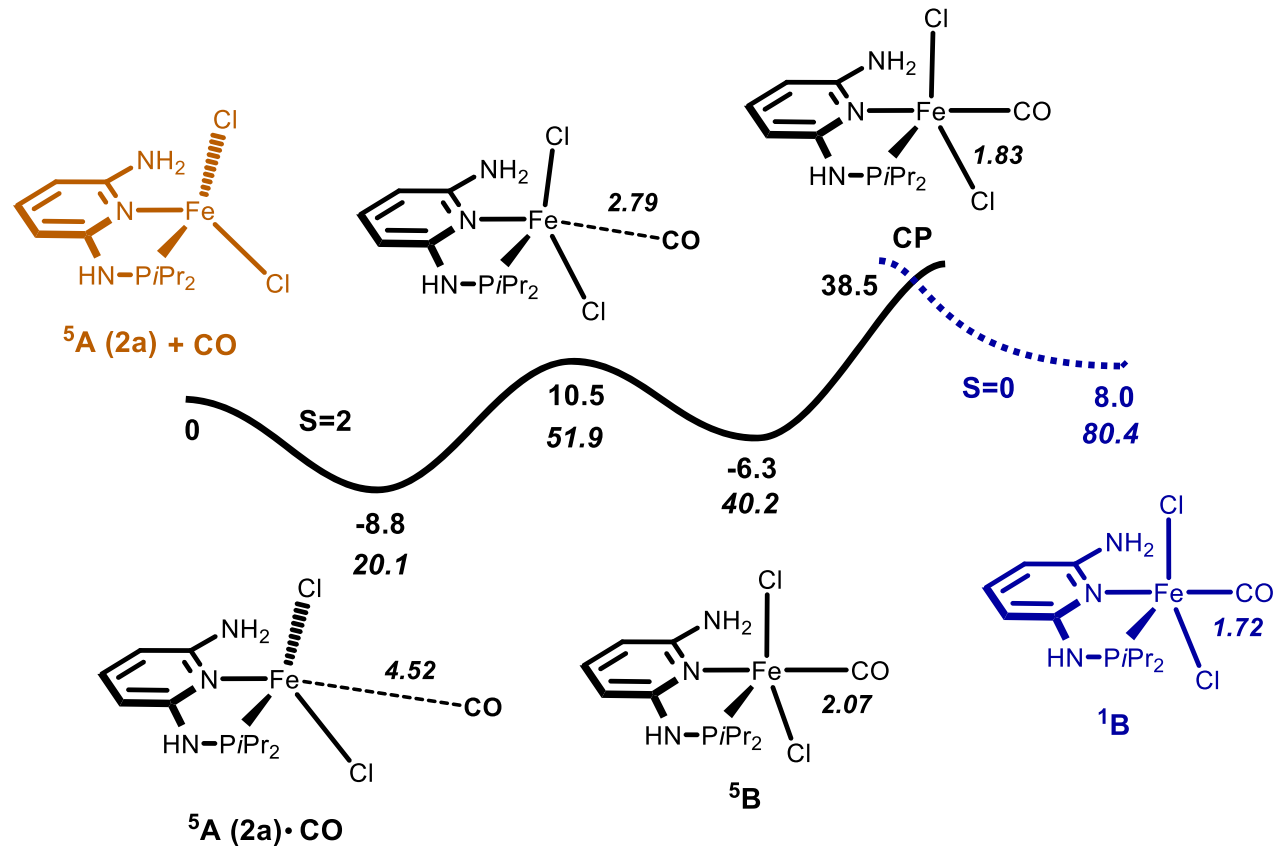

such a reaction goes through a minimum-energy crossing point (MECP) of the two potential energy surfaces (PES) involved [17]. Once that point is reached, there is a given probability for the system to change spin state and hop from one PES to the other and, thus, give rise to a "spinforbidden" or "non-adiabatic" reaction [18].

Starting with the separated reactants and following the $S=2$ PES, there is formation of a van der Waals pair between the two reacting molecules ${ }^{\mathbf{5}} \mathbf{A} \cdot \mathbf{C O}$ with a rather long $\mathrm{Fe}-\mathrm{C}(\mathrm{CO})$ distance $(4.52 \AA)$, and the corresponding small stabilization of the system $(\Delta E=-8.8 \mathrm{~kJ} / \mathrm{mol})$.
From here, the high spin isomer of the product $\left({ }^{5} \mathbf{B}\right)$ is formed in a single step going over an accessible energy barrier $\left(\Delta E^{\#}=19.3 \mathrm{~kJ} / \mathrm{mol}\right)$. The formation of ${ }^{\mathbf{5}} \mathbf{B}$ is lightly endergonic with $\Delta E=2.5 \mathrm{~kJ} / \mathrm{mol}$, showing that intermediate ${ }^{\mathbf{5}} \mathbf{B}$ is slightly less stable than the corresponding pair of reactants. After the formation of the high spin $\mathrm{CO}$ adduct ${ }^{\mathbf{5}} \mathbf{B}$, the strongly $\pi$-accepting ligand $\mathrm{CO}$ may promote a spin change to form the corresponding low-spin complex ${ }^{\mathbf{1}} \mathbf{B}(S=0)$. The MECP between the two potential energy surfaces $(\mathbf{C P})$ is easily reached, with an associated energy barrier of $\Delta E=46.9 \mathrm{~kJ} / \mathrm{mol}$. Once the crossing 
point $\mathbf{C P}$ is reached and the hopping between surfaces is accomplished, the system follows the $S=0$ PES downhill until the formation of the low $\operatorname{spin}{ }^{\mathbf{1}} \mathbf{B}$. However, this process is unfavorable with the putative low-spin product ${ }^{\mathbf{1}} \mathbf{B}$ being $14.3 \mathrm{~kJ} / \mathrm{mol}$ less stable than ${ }^{\mathbf{5}} \mathbf{B}$ and less stable by $8.0 \mathrm{~kJ} / \mathrm{mol}$ with respect to the initial separated reagents ${ }^{\mathbf{5}} \mathbf{A}$ and CO. Importantly, the overall balance for the reactions considering free energy values (values in italics in Fig. 3), indicate that $\mathrm{CO}$ addition to ${ }^{\mathbf{5}} \mathbf{A}$ is clearly endergonic $\left(\Delta G=40.2 \mathrm{~kJ} / \mathrm{mol}\right.$ for ${ }^{\mathbf{5}} \mathbf{B}$ and even $80.4 \mathrm{~kJ} / \mathrm{mol}$ for $\left.{ }^{1} \mathbf{B}\right)$. Also the formation of an illusive dicarbonyl complex $\left[\mathrm{Fe}\left(\kappa^{2} P, N-\mathrm{PN}{ }^{\mathrm{NH} 2}-i \mathrm{Pr}\right)(\mathrm{CO})_{2} \mathrm{Cl}_{2}\right](\mathbf{C})$ (not shown in Fig. 3) is endergonic by $43.5 \mathrm{~kJ} / \mathrm{mol}$. This indicates thermodynamically unfavorable processes being in good accordance with the experimental results, since formation of $\mathrm{CO}$ adducts were not observed.

In conclusion, we describe here the synthesis of several new monophosphorylated 2,6-diaminopyridine ligands bearing $\mathrm{PiPr}_{2}$ and $\mathrm{P} t \mathrm{Bu}_{2}$ units $\left(\mathrm{PN}^{\mathrm{NH} 2}-i \mathrm{Pr}, \mathrm{PN}^{\mathrm{NH} 2}-t \mathrm{Bu}\right.$, $\mathrm{PN}^{\mathrm{NHMe}}-i \mathrm{Pr}$, and $\left.\mathrm{PN}^{\mathrm{NHEt}}-i \mathrm{Pr}\right)$. These ligands react with anhydrous $\mathrm{FeCl}_{2}$ to afforded the coordinatively unsaturated paramagnetic complexes $\left[\mathrm{Fe}\left(\kappa^{2} P, N-\mathrm{PN}^{\mathrm{NH} 2}-i \mathrm{Pr}\right) \mathrm{Cl}_{2}\right]$ and $\left[\kappa^{2} P, N-\mathrm{Fe}\left(\mathrm{PN}^{\mathrm{NH} 2}-t \mathrm{Bu}\right) \mathrm{Cl}_{2}\right]$, while with $\mathrm{PN}^{\mathrm{NHMe}}-i \mathrm{Pr}$ and $\mathrm{PN}^{\mathrm{NHEt}}-i \mathrm{Pr}$ a phosphine transfer reaction of a second $\mathrm{PN}$ ligand took place to yield the known PNP pincer complexes $\left[\mathrm{Fe}\left(\kappa^{3} P, N, P-\mathrm{PNP}^{\mathrm{Me}}-i \mathrm{Pr}\right) \mathrm{Cl}_{2}\right]$ and $\left[\mathrm{Fe}\left(\kappa^{3} P, N, P\right.\right.$ $\left.\left.\mathrm{PNP}^{\mathrm{Et}}-i \mathrm{Pr}\right) \mathrm{Cl}_{2}\right]$. The four-coordinate complexes did not react with $\mathrm{CO}$ and formation of iron $\mathrm{PNC}$ pincer complexes was not observed. The reason for the reluctance to add $\mathrm{CO}$ was investigated in detail by DFT calculations indicating a thermodynamically unfavorable process.

\section{Experimental}

All manipulations were performed under an inert atmosphere of argon using Schlenk techniques or in an MBraun inert-gas glovebox. The solvents were purified according to standard procedures [19]. The ligands $N^{2}$-(diisopropylphosphanyl)pyridine-2,6-diamine $\left(\mathrm{PN}^{\mathrm{NH} 2}-i \mathrm{Pr}\right)(\mathbf{1 a}), N^{2}$ (di-tert-butylphosphanyl)pyridine-2,6-diamine $\quad\left(\mathrm{PN}^{\mathrm{NH}}\right.$ $t \mathrm{Bu}$ ) (1b) were prepared according to the literature [15]. The deuterated solvents were purchased from Aldrich and dried over $4 \AA$ molecular sieves. ${ }^{1} \mathrm{H},{ }^{13} \mathrm{C}\left\{{ }^{1} \mathrm{H}\right\}$, and ${ }^{31} \mathrm{P}\left\{{ }^{1} \mathrm{H}\right\}$ NMR spectra were recorded on Bruker AVANCE-250, AVANCE-300 DPX, and AVANCE-400 spectrometers. ${ }^{1} \mathrm{H}$ and ${ }^{13} \mathrm{C}\left\{{ }^{1} \mathrm{H}\right\}$ NMR spectra were referenced internally to residual protio-solvent, and solvent resonances, respectively, and are reported relative to tetramethylsilane $(\delta=0 \mathrm{ppm}) .{ }^{31} \mathrm{P}\left\{{ }^{1} \mathrm{H}\right\} \quad \mathrm{NMR}$ spectra were referenced externally to $\mathrm{H}_{3} \mathrm{PO}_{4}(85 \%)(\delta=0 \mathrm{ppm})$.

All mass spectrometric measurements were performed on an Esquire $3000^{\text {plus }}$ 3D-quadrupole ion trap mass spectrometer (Bruker Daltonics, Bremen, Germany) in positive-ion mode by means of electrospray ionization (ESI). Mass calibration was done with a commercial mixture of perfluorinated trialkyl-triazines (ESI Tuning Mix, Agilent Technologies, Santa Clara, CA, USA). All analytes were dissolved in methanol "hypergrade for LC-MS Lichrosolv" quality (Merck, Darmstadt, Germany) to form a concentration of roughly $1 \mathrm{mg} / \mathrm{cm}^{3}$. Direct infusion experiments were carried out using a Cole Parmer model 74900 syringe pump (Cole Parmer Instruments, Vernon Hills, IL, USA) at a flow rate of $2 \mathrm{~mm}^{3} / \mathrm{min}$. Full scan and MS/MS (low energy CID)scans were measured in the $m / z$ range 100-1100 with the target mass set to $\mathrm{m} / z=1000$. Further experimental conditions include: drying gas temperature: $150{ }^{\circ} \mathrm{C}$; capillary voltage: $-4 \mathrm{kV}$; skimmer voltage: $40 \mathrm{~V}$; octapole and lens voltages: according to the target mass set. All mass calculations are based on the most abundant metal isotope ${ }^{56} \mathrm{Fe}$ and the $\mathrm{Cl}$ isotope of lowest mass $\left({ }^{35} \mathrm{Cl}\right)$. Mass spectra were averaged during data acquisition time of 1-2 min and one analytical scan consisted of five successive micro scans resulting in 50 and 100 analytical scans, respectively, for the final full scan mass spectrum.

$N^{2}$-(Diisopropylphosphanyl)- $N^{2}, N^{6}$-dimethylpyridine-2,6amine $\left(P N^{M e, N M e}-i P r\right)\left(1 c, \mathrm{C}_{12} \mathrm{H}_{22} \mathrm{~N}_{3} \mathrm{P}\right)$

$N^{2}, N^{6}$-Dimethylpyridine-2,6-diamine $(22.96 \mathrm{mmol}, 3.15 \mathrm{~g})$ was dissolved in $100 \mathrm{~cm}^{3}$ toluene and cooled to $0{ }^{\circ} \mathrm{C}$. $n$-BuLi (24.11 mmol, $2.5 \mathrm{M}, 9.6 \mathrm{~cm}^{3}$ ) was added and the reaction was stirred at room temperature for $2 \mathrm{~h}$. After cooling to $0{ }^{\circ} \mathrm{C}$, $3.50 \mathrm{~g} \mathrm{PiPr} 2 \mathrm{Cl}$ (22.96 mmol) was added and the mixture was stirred at $80{ }^{\circ} \mathrm{C}$ for $12 \mathrm{~h}$. The reaction was quenched at room temperature by addition of $25 \mathrm{~cm}^{3}$ saturated $\mathrm{NaHCO}_{3}$ solution, the organic phase was dried over $\mathrm{Na}_{2} \mathrm{SO}_{4}$, filtered and the solvent was removed under reduced pressure. The product was used without further purification for the next step. Yield: $5.26 \mathrm{~g}(90 \%)$ yellow oil. ${ }^{1} \mathrm{H} \mathrm{NMR}\left(\mathrm{CDCl}_{3}, 20{ }^{\circ} \mathrm{C}\right): \delta=7.22$ $\left(\mathrm{t},{ }^{3} J_{H H}=7.7 \mathrm{~Hz}, 1 \mathrm{H}, \mathrm{py}^{4}\right), 6.62\left(\mathrm{bs}, 1 \mathrm{H}, \mathrm{py}^{3}\right), 5.70(\mathrm{~d}$, $\left.{ }^{3} J_{H H}=8.0 \mathrm{~Hz}, 1 \mathrm{H}, \mathrm{py}^{5}\right), 4.27(\mathrm{~s}, 1 \mathrm{H}, \mathrm{NH}), 3.02(\mathrm{~s}, 3 \mathrm{H}$, $\left.\mathrm{N}(\mathrm{H}) \mathrm{CH}_{3}\right), 2.82\left(\mathrm{~d},{ }^{3} J_{P H}=5.1 \mathrm{~Hz}, 3 \mathrm{H}, \mathrm{N}(\mathrm{P}) \mathrm{CH}_{3}\right), 2.21(\mathrm{~m}$, $\left.2 \mathrm{H}, \mathrm{CH}\left(\mathrm{CH}_{3}\right)_{2}\right), 1.08\left(\mathrm{dd},{ }^{3} J_{P H}=17.0 \mathrm{~Hz},{ }^{3} J_{H H}=7.0 \mathrm{~Hz}\right.$, $\left.6 \mathrm{H}, \mathrm{CH}\left(\mathrm{CH}_{3}\right)_{2}\right), 0.97\left(\mathrm{dd},{ }^{3} J_{P H}=12.1 \mathrm{~Hz},{ }^{3} J_{H H}=7.0 \mathrm{~Hz}\right.$, $\left.6 \mathrm{H}, \mathrm{CH}\left(\mathrm{CH}_{3}\right)_{2}\right)$ ppm; ${ }^{13} \mathrm{C}\left\{{ }^{1} \mathrm{H}\right\} \operatorname{NMR}\left(\mathrm{CDCl}_{3}, 20{ }^{\circ} \mathrm{C}\right)$ : $\delta=160.45\left(\mathrm{~d},{ }^{2} J_{C P}=20.2 \mathrm{~Hz}, \mathrm{py}^{2}\right), 158.94\left(\mathrm{~s}, \mathrm{py}^{6}\right)$, $137.07\left(\mathrm{~s}, \mathrm{py}^{4}\right), 99.37\left(\mathrm{~d},{ }^{3} J_{C P}=21.4 \mathrm{~Hz}, \mathrm{py}^{3}\right), 93.99(\mathrm{~s}$, $\mathrm{py}^{5}$ ), 33.80 (bs, $\left.\mathrm{CH}\left(\mathrm{CH}_{3}\right)_{2}\right), 29.12$ (s, N(H)CH$\left.)_{3}\right), 26.21$ (d, $\left.{ }^{2} J_{C P}=14.6 \mathrm{~Hz}, \mathrm{~N}(\mathrm{P}) \mathrm{CH}_{3}\right), 19.68\left(\mathrm{~s}, \mathrm{CH}\left(\mathrm{CH}_{3}\right)_{2}\right), 19.40(\mathrm{~d}$, $\left.{ }^{2} J_{C P}=12.7 \mathrm{~Hz}, \mathrm{CH}\left(\mathrm{CH}_{3}\right)_{2}\right) \mathrm{ppm} ;{ }^{31} \mathrm{P}\left\{{ }^{1} \mathrm{H}\right\} \mathrm{NMR}\left(\mathrm{CDCl}_{3}\right.$, $\left.20{ }^{\circ} \mathrm{C}\right): \delta=70.0 \mathrm{ppm}$.

$N^{2}$-(Diisopropylphosphanyl)- $N^{2}, N^{6}$-diethylpyridine-2,6amine $\left(P N^{E t, N E t}-i \operatorname{Pr}\left(\mathbf{1 d}, \mathrm{C}_{13} \mathrm{H}_{24} \mathrm{~N}_{3} \mathrm{P}\right)\right.$

$N^{2}, N^{6}$-Diethylpyridine-2,6-diamine (121.60 mmol, $3.75 \mathrm{~g}$ ) was dissolved in $200 \mathrm{~cm}^{3}$ toluene and $9.1 \mathrm{~cm}^{3} n$-BuLi (22.69 mmol, 2.5 M) was added at $0{ }^{\circ} \mathrm{C}$. After stirring at 
room temperature for $2 \mathrm{~h}$, the mixture was cooled to $0{ }^{\circ} \mathrm{C}$ and $3.30 \mathrm{~g} \mathrm{PiPr}{ }_{2} \mathrm{Cl}(21.60 \mathrm{mmol})$ was added. The reaction was stirred at $80{ }^{\circ} \mathrm{C}$ for $12 \mathrm{~h}$. After quenching with $25 \mathrm{~cm}^{3}$ of a saturated $\mathrm{NaHCO}_{3}$ solution, the organic phase was dried over $\mathrm{Na}_{2} \mathrm{SO}_{4}$, filtered and concentrated. The resulting yellow oil was used directly without further purification for subsequent reactions. Yield: quantitative, yellow oil. ${ }^{1} \mathrm{H}$ $\operatorname{NMR}\left(\mathrm{CDCl}_{3}, 2{ }^{\circ} \mathrm{C}\right): \delta=7.20\left(\mathrm{~m}, 1 \mathrm{H}, \mathrm{py}^{4}\right), 6.47(\mathrm{bs}, 1 \mathrm{H}$, $\left.\mathrm{py}^{3}\right), 5.67\left(\mathrm{~d},{ }^{3} J_{H H}=7.9 \mathrm{~Hz}, 1 \mathrm{H}, \mathrm{py}^{5}\right), 4.14(\mathrm{~s}, 1 \mathrm{H}, \mathrm{NH})$, $3.62\left(\mathrm{~m}, 2 \mathrm{H}, \mathrm{N}(\mathrm{P}) \mathrm{CH}_{2} \mathrm{CH}_{3}\right), 3.19\left(\mathrm{~m}, 2 \mathrm{H}, \mathrm{N}(\mathrm{H}) \mathrm{CH}_{2} \mathrm{CH}_{3}\right)$, $2.29\left(\mathrm{~m}, 2 \mathrm{H}, \mathrm{CH}\left(\mathrm{CH}_{3}\right)_{2}\right), 1.13-0.82\left(\mathrm{~m}, 18 \mathrm{H}, \mathrm{CH}_{2} \mathrm{CH}_{3}\right.$, $\left.\mathrm{CH}\left(\mathrm{CH}_{3}\right)_{2}\right) \quad$ ppm; $\quad{ }^{13} \mathrm{C}\left\{{ }^{1} \mathrm{H}\right\} \quad \mathrm{NMR} \quad\left(\mathrm{CDCl}_{3}, \quad 20^{\circ} \mathrm{C}\right)$ : $\delta=159.11\left(\mathrm{bs}, \mathrm{py}^{2}\right), 158.26\left(\mathrm{~s}, \mathrm{py}^{6}\right), 139.05\left(\mathrm{~s}, \mathrm{py}^{4}\right)$, 102.04 (bs, py $^{3}$ ), 94.28 (s, py $\left.{ }^{5}\right), 42.82$ (bs, $\mathrm{N}(\mathrm{P}) \mathrm{CH}_{2} \mathrm{CH}_{3}$ ), $36.90\left(\mathrm{~s}, \quad \mathrm{~N}(\mathrm{H}) \mathrm{CH}_{2} \mathrm{CH}_{3}\right), \quad 26.20 \quad\left(\mathrm{~d},{ }^{1} J_{C P}=15.1 \mathrm{~Hz}\right.$, $\left.\mathrm{CH}\left(\mathrm{CH}_{3}\right)_{2}\right), 19.87\left(\mathrm{~d},{ }^{2} J_{\mathrm{CP}}=10.0 \mathrm{~Hz}, \mathrm{CH}\left(\mathrm{CH}_{3}\right)_{2}\right), 19.39$ (s, $\left.\mathrm{CH}\left(\mathrm{CH}_{3}\right)_{2}\right), \quad 14.93$ (s, $\left.\mathrm{N}(\mathrm{H}) \mathrm{CH}_{2} \mathrm{CH}_{3}\right), 14.73$ (s, $\left.\mathrm{N}(\mathrm{P}) \mathrm{CH}_{2} \mathrm{CH}_{3}\right) \quad$ ppm; ${ }^{31} \mathrm{P}\left\{{ }^{1} \mathrm{H}\right\} \quad \mathrm{NMR} \quad\left(\mathrm{CDCl}_{3}, \quad 20{ }^{\circ} \mathrm{C}\right)$ : $\delta=78.8 \mathrm{ppm}$.

[Dichloro)( $N^{2}$-(diisopropylphosphanyl)pyridine-2,6-diamine)iron(II)] ([Fe( $\left.\left.\kappa^{2} \mathrm{P}, \mathrm{N}-\mathrm{PN} \mathrm{NH}_{-i} \mathrm{Pr}^{2} \mathrm{Cl}_{2}\right]\right)$

(2a, $\mathrm{C}_{11} \mathrm{H}_{20} \mathrm{Cl}_{2} \mathrm{FeN}_{3} \mathrm{P}$ )

Ligand 1a (11.33 mmol, $300 \mathrm{mg})$ was stirred with $161 \mathrm{mg}$ anhydrous $\mathrm{FeCl}_{2}(1.27 \mathrm{mmol})$ in $15 \mathrm{~cm}^{3}$ THF for $12 \mathrm{~h}$. The yellow suspension was concentrated to $0.5 \mathrm{~cm}^{3}$ and the product was precipitated with $40 \mathrm{~cm}^{3} \mathrm{Et}_{2} \mathrm{O}$. After filtration, the yellow solid was washed twice with $10 \mathrm{~cm}^{3}$ of $\mathrm{Et}_{2} \mathrm{O}$ and dried under vacuum. Yield: $352 \mathrm{mg}(79 \%)$ as yellow solid. ${ }^{1} \mathrm{H}$ NMR (acetone- $\left.d_{6}, 20^{\circ} \mathrm{C}\right): \delta=150.7 \quad(2 \mathrm{H}$, $\left.\mathrm{CH}\left(\mathrm{CH}_{3}\right)_{2}\right), 54.4(1 \mathrm{H}$, py), $45.7(1 \mathrm{H}$, py $), 16.2(6 \mathrm{H}$, $\mathrm{CH}\left(\mathrm{CH}_{3}\right)_{2},-3.4\left(6 \mathrm{H}, \mathrm{CH}\left(\mathrm{CH}_{3}\right)_{2},-19.7(1 \mathrm{H}, \mathrm{py}) \mathrm{ppm} . \mathrm{NH}\right.$ and $\mathrm{NH}_{2}$ resonances could not be detected.

[Dichloro)( $N^{2}$-(di-tert-butylphosphanyl)pyridine-2,6-diamine)iron(II)] ([Fe $\left.\left.\left(\kappa^{2} P, N-P N^{N H 2}-t B u\right) C l_{2}\right]\right)$

(2b, $\mathrm{C}_{13} \mathrm{H}_{24} \mathrm{Cl}_{2} \mathrm{FeN}_{3} \mathrm{P}$ )

This complex was prepared analogously to $2 \mathbf{a}$ with $300 \mathrm{mg}$ $1 \mathbf{b}(1.18 \mathrm{mmol})$ and $143 \mathrm{mg}$ anhydrous $\mathrm{FeCl}_{2}(1.13 \mathrm{mmol})$ as starting materials. Yield: $349 \mathrm{mg}(81 \%)$ as yellow solid.

[Dichloro) $\left(N^{2}, N^{6}\right.$-Bis(diisopropylphosphanyl)- $N^{2}, N^{6}$-dimethylpyridine-2,6-diamine $)$ iron(II)] $\quad\left(\left[\mathrm{Fe}\left(\kappa^{3} P, N, P-P N P^{M e} e_{-}\right.\right.\right.$ $\mathrm{iPr}) \mathrm{Cl}_{2}$ ]) (3a)

Asuspension of $150 \mathrm{mg}$ anhydrous $\mathrm{FeCl}_{2}(1.18 \mathrm{mmol})$ and $300 \mathrm{mg} \mathrm{1c}(1.18 \mathrm{mmol})$ was stirred in $15 \mathrm{~cm}^{3}$ THF at room temperature for $12 \mathrm{~h}$. The solvent was then removed under vacuum and the remaining solid redissolved in $15 \mathrm{~cm}^{3}$ $\mathrm{CH}_{2} \mathrm{Cl}_{2}$. Insoluble materials were removed by filtration. The volume of the solution was reduced to about $1 \mathrm{~cm}^{3}$ and the product was precipitated by addition of $40 \mathrm{~cm}^{3} \mathrm{n}$ pentane. The yellow solid was collected on a glass frit, washed twice with $10 \mathrm{~cm}^{3} n$-pentane, and dried under vacuum. Yield: $272 \mathrm{mg}$ (46\%) [16].
[Dichloro) $\left(N^{2}, N^{6}\right.$-Bis(diisopropylphosphanyl)- $N^{2}, N^{6}$-diethylpyridine-2,6-diamine)iron(II)] ([Fe $\left(\kappa^{3} P, N, P-P N P^{E t}\right.$. iPr) $\mathrm{Cl}_{2}$ ]) (3b)

This complex was prepared analogously to $\mathbf{3 a}$ with $135 \mathrm{mg}$ anhydrous $\mathrm{FeCl}_{2}(1.07 \mathrm{mmol})$ and $300 \mathrm{mg} \mathbf{1 d}(1.07 \mathrm{mmol})$ as starting materials. Yield: $269 \mathrm{mg}(48 \%)$ [16].

\section{X-ray structure determination}

X-ray diffraction data of $\left[\mathrm{Fe}\left(\kappa^{2} P, N-\mathrm{PN}^{\mathrm{NH} 2}-i \mathrm{Pr}\right) \mathrm{Cl}_{2}\right]$ (2a) (CCDC number 1449666) were collected at $T=100 \mathrm{~K}$ in a dry stream of nitrogen on a Bruker Kappa APEX II diffractometer system using graphite-monochromatized $\mathrm{MoK \alpha}$ radiation $(\lambda=0.71073 \AA)$ and fine sliced $\varphi$ - and $\omega$-scans. Data were reduced to intensity values with SAINT and an absorption correction was applied with the multi-scan approach implemented in SADABS [20]. The structures were solved by charge flipping using SUPERFLIP [21] and refined against $F$ with JANA2006 [22]. The non-hydrogen atoms were refined anisotropically. The $\mathrm{H}$ atoms connected to $\mathrm{C}$ atoms were placed in calculated positions and thereafter refined as riding on the parent atoms. $\mathrm{H}$ atoms connected to $\mathrm{N}$ were located in difference Fourier maps and the $\mathrm{N}-\mathrm{H}$ distances restrained to $0.870(1) \AA$. Molecular graphics were generated with the program MERCURY [23].

\section{Computational details}

Calculations were performed using the GAUSSIAN 09 software package [24], and the OPBE functional [25-28] without symmetry constraints. This functional combines Handy's OPTX modification of Becke's exchange functional with the gradient corrected correlation functional of Perdew, Burke, and Ernzerhof, and was shown to be accurate in the calculation of spin state energy splitting for first transition row species and, in particular, for iron complexes [29-31]. The optimized geometries were obtained with the Stuttgart/Dresden ECP (SDD) basis set [32-34] to describe the electrons of the iron atom. For all other atoms a standard $6-31 \mathrm{G}^{* *}$ basis set was employed [35-40]. Transition state optimizations were performed with the Synchronous Transit-Guided Quasi-Newton Method (STQN) developed by Schlegel et al. [41, 42], following a thorough search of the Potential Energy Surfaces (PES). Frequency calculations were performed to confirm the nature of the stationary points, yielding one imaginary frequency for the transition states and none for the minima. Each transition state was further confirmed by following its vibrational mode downhill on both sides, and obtaining the minima presented on the energy profiles.

The Minimum Energy Crossing Points (MECP) between PES of two different spin states were determined using a 
code developed by Harvey et al. [43]. This code consists of a set of shell scripts and Fortran programs that use the Gaussian results of energies and gradients of both spin states to produce an effective gradient pointing towards the MECP.

Electronic energy values are presented in the profiles and discussed along the text because MECP are not stationary points and, hence, a standard frequency analysis is not applicable. However, free energy values are also presented for all stationary points, for comparison purposes. Those values were obtained from the electronic energies at $298.15 \mathrm{~K}$ and $1 \mathrm{~atm}$ using zero point energy and thermal energy corrections based on structural and vibration frequency data and were further corrected for dispersion effects by means of Grimme DFT-D3 method [44] with Becke and Jonhson short distance damping [45-47].

Acknowledgments Financial support by the Austrian Science Fund (FWF) is gratefully acknowledged (Project No. P24202-N17). LFV acknowledges Fundação para a Ciência e Tecnologia, Projecto Estratégico-PEst-OE/QUI/UI0100/2013. The X-ray center of the Vienna University of Technology is acknowledged for financial support and for providing access to the single-crystal diffractometer.

Open Access This article is distributed under the terms of the Creative Commons Attribution 4.0 International License (http:// creativecommons.org/licenses/by/4.0/), which permits unrestricted use, distribution, and reproduction in any medium, provided you give appropriate credit to the original author(s) and the source, provide a link to the Creative Commons license, and indicate if changes were made.

\section{References}

1. Gossage RA, van de Kuil LA, van Koten G (1998) Acc Chem Res 31:423

2. van der Boom ME, Milstein D (2003) Chem Rev 103:1759

3. Albrecht M, van Koten G (2001) Angew Chem Int Ed 40:3750

4. Morales-Morales D, Jensen CM (eds) (2007) The Chemistry of Pincer Compounds. Elsevier, Amsterdam

5. Murugesan S, Kirchner K (2016) Dalton Trans 45:416

6. Benito-Garagorri D, Lagoja I, Veiros LF, Kirchner KA (2011) DaltTrans 40:4778

7. Zuo JL, Fu WF, Che CM, Cheung KK (2003) Eur J Inorg Chem 2003:255

8. Nombel P, Lugan N, Donnadie B, Lavigne G (1988) Organometallics 18:187

9. Tomon T, Koizumi TA, Tanaka K (2005) Angew Chem Int Ed 44:2229

10. Teo AKL, Fan WY (2014) Chem Commun 50:7191

11. Turrell PJ, Wright JA, Peck JNT, Oganesyan VS, Pickett CJ (2010) Angew Chem Int Ed 49:7508

12. Turrell PJ, Hill AD, Ibrahim SK, Wright JA, Pickett CJ (2013) Dalton Trans 42:8140

13. Benito-Garagorri D, Wiedermann J, Pollak M, Mereiter K, Kirchner K (2007) Organometallics 26:217

14. Benito-Garagorri D, Alves LG, Puchberger M, Mereiter K, Veiros LF, Calhorda MJ, Carvalho MD, Ferreira LP, Godinho M, Kirchner K (2009) Organometallics 28:6902
15. Holzhacker C, Stöger B, Carvalho MD, Ferreira LP, Pittenauer E, Allmaier G, Veiros LF, Realista S, Gil A, Calhorda MJ, Müller D, Kirchner K (2015) Dalton Trans 44:13071

16. Glatz M, Holzhacker C, Bichler B, Mastalir M, Stöger B, Mereiter K, Weil M, Veiros LF, Mösch-Zanetti NC, Kirchner K (2015) Eur J Inorg Chem 2015:5053

17. Harvey JN, Poli R, Smith KM (2003) Coord Chem Rev 238-239:347

18. Harvey JN (2007) Phys Chem Chem Phys 9:331

19. Perrin DD, Armarego WLF (1988) Purification of Laboratory Chemicals, 3rd edn. Pergamon Press, New York

20. Bruker computer programs (2012) APEX2, SAINT and SADABS. Bruker AXS Inc., Madison, WI

21. Palatinus L, Chapuis G (2007) J Appl Cryst 40:786

22. Petříček V, Dušek M, Palatinus L (2006) JANA2006, the crystallographic computing system. Institute of Physics, Praha, Czech Republic

23. Macrae CF, Edgington PR, McCabe P, Pidcock E, Shields GP, Taylor R, Towler M, van de Streek J (2006) J Appl Cryst 39:453

24. Frisch MJ, Trucks GW, Schlegel HB, Scuseria GE, Robb MA, Cheeseman JR, Scalmani G, Barone V, Mennucci B, Petersson GA, Nakatsuji H, Caricato M, Li X, Hratchian HP, Izmaylov AF, Bloino J, Zheng G, Sonnenberg JL, Hada M, Ehara M, Toyota K, Fukuda R, Hasegawa J, Ishida M, Nakajima T, Honda Y, Kitao O, Nakai H, Vreven T, Montgomery JA Jr, Peralta JE, Ogliaro F, Bearpark M, Heyd JJ, Brothers E, Kudin KN, Staroverov VN, Kobayashi R, Normand J, Raghavachari K, Rendell A, Burant JC, Iyengar SS, Tomasi J, Cossi M, Rega N, Millam JM, Klene M, Knox JE, Cross JB, Bakken V, Adamo C, Jaramillo J, Gomperts R, Stratmann RE, Yazyev O, Austin AJ, Cammi R, Pomelli C, Ochterski JW, Martin RL, Morokuma K, Zakrzewski VG, Voth GA, Salvador P, Dannenberg JJ, Dapprich S, Daniels AD, Farkas Ö, Foresman JB, Ortiz JV, Cioslowski J, Fox DJ (2009) Gaussian 09, revision A.02. Gaussian Inc., Wallingford

25. Handy NC, Cohen AJ (2001) Mol Phys 99:403

26. Hoe WM, Cohen A, Handy NC (2001) Chem Phys Lett 341:319

27. Perdew JP, Burke K, Ernzerhof M (1997) Phys Rev Lett 78:1396

28. Perdew JP, Burke K, Ernzerhof M (1996) Phys Rev Lett 77:3865

29. Swart M (2008) J Chem Theory Comput 4:2057

30. Conradie J, Ghosh A (2007) J Chem Theory Comput 3:689

31. Conradie J, Ghosh A (2007) J Phys Chem B 111:12621

32. Haeusermann U, Dolg M, Stoll H, Preuss H (1993) Mol Phys 78:1211

33. Kuechle W, Dolg M, Stoll H, Preuss H (1994) J Chem Phys 100:7535

34. Leininger T, Nicklass A, Stoll H, Dolg M, Schwerdtfeger $P$ (1996) J Chem Phys 105:1052

35. McLean AD, Chandler GS (1980) J Chem Phys 72:5639

36. Krishnan R, Binkley JS, Seeger R, Pople JA (1980) J Chem Phys 72:650

37. Hay PJ (1977) J Chem Phys 66:4377

38. Raghavachari K, Trucks GW (1989) J Chem Phys 91:1062

39. Binning RC, Curtiss LA (1995) J Comput Chem 103:6104

40. McGrath MP, Radom L (1991) J Chem Phys 94:511

41. Peng C, Ayala PY, Schlegel HB, Frisch MJ (1996) J Comp Chem 17:49

42. Peng C, Schlegel HB (1994) Israel J Chem 33:449

43. Harvey JN, Aschi M, Schwarz H, Koch W (1998) Theor Chem Acc 99:95

44. Grimme S, Antony J, Ehrlich S, Krieg HJ (2010) Chem Phys 132:154104

45. Becke AD, Johnson ER (2005) Chem Phys 122:154101

46. Johnson ER, Becke AD (2005) J Chem Phys 123:24101

47. Johnson ER, Becke AD (2006) J Chem Phys 124:174104 